\title{
La invitación es a participar
}

En este, mi primer número como Editor Científico de la Revista de la Sociedad Chilena de Radiología, quiero saludar e invitar a todos los médicos, científicos y profesionales ligados a las imágenes médicas, a tomar parte activa de nuestra comunidad. Invitarlos a leer nuestras publicaciones, a proponer temas y artículos para que juntos enriquezcamos el debate y compartamos nuestras experiencias y conocimientos para ir avanzando nuestro campo y ser partícipes activos del cómo éste tiene un impacto en la salud y en la comprensión de las enfermedades en nuestra población. Así, en conjunto podemos contribuir en mejorar nuestra labor en la entrega de diagnósticos y en la toma de decisiones de la atención de nuestros pacientes.

Con mucha responsabilidad asumo este rol de editor científico de la Revista de la Sociedad Chilena de Radiología, trabajo que asumo tras un concurso abierto hecho por el presente directorio de la sociedad. Tomo esta tarea como un gran desafío personal, profesional y académico, y trabajaré con el fin de responder a los intereses de nuestros lectores y enfocado en seguir avanzando en el potencial educativo y de divulgación de casos, experiencias e investigaciones locales y regionales que se relacionen con las imágenes médicas. Para esto, entre otras medidas, empezaremos implementando este año nuestro nuevo portal de envío de manuscritos, tras un trabajo en conjunto con SciELO y CONICYT, que consta de un Open Journal System (OJS), para hacer más expedito el proceso de envío y revisión de los trabajos enviados.

Es con algo de atraso que logramos ensamblar el primer número de este año en el cual se encontrarán con interesantes artículos y casos que entregan de temas variados. Así, el artículo "Magnitudes y unidades para dosimetría del personal ocupacionalmente expuesto en radiodiagnóstico e intervencionismo", destaca por describir en un lenguaje sencillo las principales magnitudes y unidades que se deben conocer y utilizar en la dosimetría ocupacional de los trabajadores que participan en procedimientos de Radiodiagnóstico; el texto "PieloRM: Una nueva herramienta en el estudio de pielonefritis aguda en pediatría" resulta interesante debido a que presenta una alternativa viable sin radiaciones ionizantes a los estudios de medicina nuclear en este escenario, cuando estos no estén disponibles o no puedan ser realizados; o el caso "Lesión por estrés de la fisis distal del fémur. Reporte de un caso y revisión del tema", muestra un tipo de lesión que está siendo más frecuente dado el aumento de los deportistas de mayor rendimiento, en que la RM es clave para el diagnóstico, artículo que complementa muy bien la excelente revisión del caso "Lesiones musculares deportivas: Correlación entre anatomía y estudio por imágenes"; "Imágenes en trasplante de páncreas: Que debemos buscar", que muestra de una manera didáctica y comprensible para el lector menos experimentado las imágenes de un procedimiento cada vez más frecuente, pero aún desconocido para muchos especialistas. Además, está el "Portograma aéreo y neumatosis intestinal como hallazgos incidentales enpostoperatorio de cirugía abdominal", un hallazgo benigno, pero que puede inducir a confusión sobre todo en ausencia de antecedentes clínicos. Además, para iniciar nuestras publicaciones del año 2018 incluimos un artículo de interés sobre "Respeto de intimidad y dignidad del paciente", donde los autores describen los potenciales conflictos a los que puede estar expuesto el radiólogo para salvaguardar la información confidencial del paciente, de especial relevancia en la era de digitalización de las imágenes y las oportunidades de compartir estas por la red.

Reitero la invitación a formar de la Revista Chilena de Radiología. Como nunca, existe hoy una masa crítica de residentes de distintos programas, en distintas regiones del país, varios programas de sub-especialidad y múltiples profesionales altamente capacitados trabajando en centros académicos y/o con interés docente. Creo que todos, desde nuestros distintos frentes y contextos laborales podemos aportar, como autores, revisores y lectores, en mejorar el trabajo de nuestra especialidad y utilizar nuestra principal vía de difusión para fortalecer la comunidad.

Juan Pablo Cruz Q.

Editor Científico

Departamento de Radiología

Pontificia Universidad Católica de Chile. Santiago, Chile.

revista@sochradi.cl 